\title{
Tourism SME sustainability social and economic challenges during pandemic: cases of Russian Federation, Georgia and Latvia
}

\author{
Kristine Berzina ${ }^{1}$, and Marina Tsoy $^{2}$ \\ ${ }^{1}$ University of Latvia, Riga, Latvia \\ ${ }^{2}$ Novosibirsk State Technical University, Novosibirsk, Russian Federation
}

\begin{abstract}
Until 2020, the tourism industry was characterized by a growth rate, the statistics highlight that globally 2019 was the tenth year with a consecutive annual growth. However, the Covid-19 pandemic marked a major turning point in the development of tourism, instead of tourism overdevelopment, the underdevelopment issues appeared in front pages of the industry news. The effects of the pandemic are intensified by the fact that tourism is a labour-intensive industry and that most companies in the sector are SMEs (small and medium sized enterprises). At this time, it is crucially important to look at sustainability issues, therefore the aim of this study is to analyse the social and economic dimensions of sustainability for tourism SMEs. Descriptive statistics as well as qualitative research methods were used to study the challenges posed by the pandemic, indepth interviews were conducted with tourism SMEs from three different countries. The conclusions show the situation from an enterprise perspective in Russian Federation, Georgia and Latvia.
\end{abstract}

\section{Introduction}

Tourism industry can be characterised as a great contributor to the world economy from an economic perspective. According to the World Travel and Tourism Council (WTTC) data [1], the industry accounted for approximately $10 \%$ of the world's GDP in 2019. From the social perspective, the tourism industry employed over 319 million people in 2019, thus emerging or already developed economies as well as small countries depend largely on the tourism industry. Tourism researchers also outline above mentioned positive contributions of tourism development to the economy, as the most important emphasizing skilled and low-skilled job creation, investment attraction, and socio-economic development [2], still other researchers $[2,3]$ emphasize negative consequences for sustainability created by mass tourism and over-tourism. Tourism is an industry that has a significantly big impact on sustainable development. The United Nations (UN) General Assembly announced the year 2017 as the International Year of Sustainable Tourism for Development, and during the last few years, the importance of sustainability has not decreased. Scientists have done considerable research about the issues of sustainability and evolution of sustainability in terms of the tourism industry [4], still in many theories there is no universally accepted definition of sustainable tourism destinations [5]. Generally, lists of different terms are used 
as synonymous when talking about sustainable tourism, like responsible tourism and ethical tourism, as indicated by scholars, all embrace the key parameters of sustainability within the tourism sector [6]. The approach of some scientists should also be mentioned, who argue that sustainable tourism development generally is not possible per se [7]. Thus it is important to frame that sustainable tourism means minimisation of the negative social, economic and environmental impacts, and maximisation of the positive social, economic and environmental impacts of tourism in destination communities and environments. It can be done by promoting ethical consumption and production among tourists and all stakeholders [8,9], and it would generate greater economic benefits for local people or involve local people in decisions that affect their lives and life chances [10]. A traditional visualization of sustainable development dimensions is a Venn diagram with three pillars of sustainability in which social, economic and environmental factors overlap, so as to produce a system that is sustainable in that it is socially bearable, economically equitable and environmentally viable [11]. The number of publications on sustainability is considerable, the research of recent publications reveals that even in the tourism sector, the Sustainable Development Goals (SDG) represent a new research frontier for scholars and the number of research articles is increasing steadily [12]. The global tourism industry has been stopped and concern about overtourism has suddenly been replaced by opposite worry - undertourism that can endanger future economies and social aspects of worldwide development [9] Many scholars' studies show cooperation programs are not economically effective, still some researchers see potential for socio-economic development [13] Tourism is one of the most labour-intensive sectors of the economy, and it is among those that are most affected by the pandemic and the pandemic situation pressure is pushing on both social as well as economic sustainability $[14,15]$.Sustainable socio-economic development as such should be based on both the economic as well as social aspects, it must consider the complex balance of incomes and outcomes of resources used [16 ]. As indicated by Skvarciany, Jureviciene, Volskyte, there are not many researchers who investigate socioeconomic development specifically from the economic perspective [17]. Scientists are still discussing, which factors are influencing sustainable socio-economic development [17] The economic and social paradigm of sustainable development in Agenda 21 [18, 19] as economic sustainability criteria mention growth, development, productivity, and for social sustainability equity sharing, empowerment, accessibility, participation, cultural identity, institutional stability. Socio-economic sustainability includes two sustainability pillarssocial and economic; hence, where social sustainability refers to the improvement of living conditions for current and future generations [20], and economic sustainability refers to the ability of the economy to support and maintain economic growth by efficient natural resource usage. Combining both pillars, socio-economic sustainability can be described as the ability to ensure economic growth without undermining human interests and to meet their needs without harming nature [17].

General attributes of sustainable systems in MESMIS (Assessing the Sustainability of Natural Resource Management Systems) framework are social well-being as well as economic resilience, including productivity and profitability, stability of production, stability of supply, risk management, private investment, value creation, reliability, adaptability, self-reliance or so called self-empowerment, and good governance [21, 17].

As the core of MESMIS framework [22] sustainability is defined by following systemic and dynamic attributes as productivity, stability, reliability, resilience, adaptability, equity and self-reliance. Scholars outline socio-economic sustainability can be achieved by high levels of productivity through the efficient and synergistic use of natural and economic resources, by maintaining reliable, stable and resilient production, providing access to the production assets; promoting the renewable use of local resources; integrating adequate diversity of the natural environment with economic activities; incorporating risk prevention 
and reduction mechanisms [21]. Tourism enterprises, especially SMEs that dominate the tourism industry, nowadays face many difficulties and threats to their survival. Before the Covid-19 pandemic, it was the economic globalization, the proliferation of large commercial or industrial chains, the inconstancy and mutation of the environment, and the economic crisis. These are some of the variables that threaten the businesses [23], now the impact by the pandemic has shocked companies, especially those that have not worked timely on crisis management measures. When tourism SMEs are chosen as case studies, it should be noted that especially for micro and small enterprises the owner's personal motivations impact how business decisions are made to a great extent and non-financial motivations could also be a driver for behaviours [24].

\section{Descriptive research of tourism development before and during Covid-19 pandemic}

In order to get an insight into the current development trends, descriptive research is based on secondary data quantitative analyses of the main socio-economic tourism indicators. As indicated by WTTC before the pandemic, the most significant social importance indicator is employment, it provided 334 million workplaces for the Travel \& Tourism industry globally (direct, indirect, induced, 2019) that is $10.6 \%$ of all jobs. The most used economic significance indicator is the Travel \& Tourism industry GDP. In 2019, it was US\$ 9.2 trillion, which is $10.4 \%$ from global GDP. Nevertheless the situation in each of the three analysed countries is different.

According to the statistics of the Russian Federation, the country is relatively less dependent on tourism development. Before the pandemic, total contribution of tourism to the economy was only $4.9 \%$, which decreased by $47 \%$ as a result of the pandemic, falling to $2.7 \%$ share of the total economy. If we look at social indicators, the reduction of the workforce in the Russian Federation during the pandemic is relatively small by only $5.1 \%$, from 4039.7 thousand employees to 3834.0 thousand. One of the indicators of sustainability is domestic tourism spending, which in Russian Federation is quite high, comprising 50\% of total tourism, keeping the country in the top 20 countries in terms of Travel \& Tourism's total size of domestic spending [25]. Domestic tourism spending during the pandemic decreased by $43.9 \%$, from 37.9 billion dollars in 2019 to 21.3 billion in 2020 . Tourism, like many other industries, found itself in a difficult economic situation in 2020 due to the imposition of restrictions related to the COVID-19 pandemic. Inbound tourism was actually stopped, and most of the foreign routes for Russians were closed. Inbound tourism to Russia in 2020 decreased by more than $90 \%$. According to the estimates of the Association of Tour Operators (ATOR), the total flow of domestic tourists in Russia decreased by 35 $40 \%$ i.e., from 68 million trips in 2019 to about 40 million in 2020. From the most popular tourist destinations, St. Petersburg and Moscow suffered the most damage. Many travel companies were forced to suspend their activities, or even be liquidated altogether.

Analysing Georgia's statistics, the country's dependence on the development of the tourism sector stands out, as the total contribution of tourism to the total economy before the pandemic was even more than quarter of their economy $(26.8 \%)$, which is two and a half times higher than the world average (10.4\% in 2019). As a result of the pandemic, the share of the tourism sector in the total national economy decreased very sharply by $72.1 \%$, falling to $7.9 \%$ of the total economy. The social employment indicator is also more critical in Georgia, workforce fell by $26.5 \%$ during the pandemic, from 517.2 thousand employees to 380.3 thousand. During the pandemic, the volume of domestic tourism decreased by $45.7 \%$ - from 1365.3 million dollars in 2019 to 741.2 million in 2020.

Looking at Latvia's statistical indicators, it can be seen that the total contribution of tourism to the economy before the pandemic was $7.7 \%$, which decreased by half $(50,4 \%)$ as 
a result of the pandemic, falling to $4.0 \%$ of the total economy. Analyzing the social indicators during the pandemic, the workforce decreased by $11.1 \%$, from 75.6 thousand to 67.2 thousand people employed. The situation in Latvia is quite similar to the decline of domestic tourism spending as in both previously analysed countries, decreasing by $42.6 \%$ from 1,040 million dollars in 2019 to 596.6 million dollars in 2020. The overall statistical data show general tendencies, however deeper analyses of the situation can be conducted by in-depth interviews.

\section{Results and discussion on social and economic SME sustainability challenges during the pandemic}

In-depth interviews can be considered as democratic and emancipating forms of social research since it may provide an opportunity to present a variety of views and experiences $[26,27]$. Semi-structured interviews allow a collection of detailed information for a comparatively small sample and avoid problems related to incorrect interpretation of the questions [28]. Interview questions were developed based on literature review on social and economic dimensions of sustainability applying the main principles of MESMIS. For the tourism industry, twelve SME companies were chosen for interviews based on a principle of variety. The in-depth interviews were conducted from September 2020 till June 2021. Based on the analysis, authors made conclusions on tourism SME social and economic sustainability in all three countries.

Analysing the socio-economic situation, Russian Federation as a large country with a wide range of domestic tourism development, especially during the last years, led to a comparatively less negative effect by the Covid-19 pandemic. Between April and October 2020, the Russian government approved a number of initiatives aimed at supporting key sectors of the economy, including tourism, for example, a cashback program for trips within the country. Another popular measure of support at the federal level was subsidies for salaries of travel company employees. Delays and instalments of tax and rental payments did not have an effect for tourist businesses, being non-working instruments. In 2020, 474 individual entrepreneurs and organizations of the tourist and hotel sector received subsidies from the federal budget for grant support of public and business initiatives aimed at the development of domestic and inbound tourism. The grant amount ranged from 130 thousand rubbles up to 3 million rubbles. According to interviews, the actions of the authorities will accelerate the recovery of the tourism sector from the consequences of the coronavirus pandemic. Thus, travel companies will be able to compensate for the losses and keep the flow of tourists during this difficult period.

In the interviews with Georgian accommodation establishments, both the capital and the periphery companies acknowledged that they had not received any or only negligible government support during the pandemic. Especially in companies outside the capital, scepticism about government support and the struggle for survival was very sharply outlined in all interviews. Social sustainability measures during the pandemic theoretically have been adopted by Georgian government; still, interviews showed that a big part of SMEs and their employees did not receive it.

The interviews with Latvian companies were interesting due to one case - a campsite that used the pandemic and the support systems offered by the state to make the company more environmentally friendly, as well as socially and economically sustainable. During the pandemic, work was done to adapt the product to the principles of sustainability and environmentally friendly operation, staff was trained, and the company used all available financial support instruments offered by the state. However, this is more than a separate case. Generally accommodation establishments during the pandemic relied on the 
possibility to attract local tourists or inbound tourists from nearby countries in the summer of 2020, which was more feasible for rural and holiday accommodations than capital hotels.

\section{Conclusions}

1. Although people travel more sustainably within their own country as a result of the pandemic, spending on local tourism has decreased during the pandemic in all three countries analysed.

2. The Russian Federation used not only tourism supply, but also tourism demand support measures to heat local tourism.

3. The Georgian economy is most dependent on the tourism sector, and it is in Georgia that the least number of interviewed companies received state support.

4. A separate case in Latvia proved that the pandemic time can be used for the application and development of a company's strategy for sustainability and environmental friendliness.

\section{Acknowledgements}

The article has been prepared with support of Horizon project "New Market: an exploration into the changing nature of business environments, informal barriers and emerging markets in the post-Soviet region."

\section{References}

1. WTTC, 2021 Annua research, key highlights (2021) https://wttc.org/

2. N.P. Canh, S.D. Thanh, Annals of tourism research, 85 (2020)

3. H. Seraphin, P. Sheeran, M. Pilato, Journal of Destination Marketing \& Management, 9, 374 (2018)

4. N. Yuzbasioglua, Y. Topsakal, P. Celikc, Procedia - Social and Behavioral Sciences, 150, 968 (2014)

5. K.F. Lee, Journal of Cleaner Production, 9, 313 (2001)

6. L.K Haywood, K. Nortje, G. Dafuleya, T.Nethengwe, F. Sumbana, Development Southern Africa, 37(6), 1033 (2020)

7. V.C. Westmont, Tourism Planning and Development, 18(1), 45 (2021)

8. J. Saarinen, Annals of Tourism Research, 33 (4), 1121 (2006)

9. W. Marek, Sustainability (Switzerland), 13(4), 1 (2021)

10. A.R. Szromek, Journal of Open Innovation: Technology, Market, and Complexity, 7 (1), 1 (2021)

11. E. Dalampira, S.A. Nastis, International Journal of Sustainable Agricultural Management and Informatics, 6(3), 226 (2020)

12. P.F. Rosato, A. Caputo, D. Valente, S. Pizzi, Ecological Indicators, 121 (2021)

13. E. Kropinova, Sustainability (Switzerland), 13(4), 1 (2021)

14. C. Yin, W. Zhao, F. Cherubini, P. Pereira, Geography and Sustainability, 2(1), 68 (2021)

15. O. Almukhamedova, International Journal of Criminology and Sociology, 9, 1237 (2020) 
16. A. Tuziak, Socio-Economic Aspects of Sustainable Development on Global and Local Level (2010)

17. V. Skvarciany, D. Jurevičienè, G. Volskytè, Sustainability, 12(5), 1 (2020)

18. M. Kahn, Proceedings of the 1995 International Sustainable Development Research Conference, 63 (1995)

19. A.D. Basiago, The Environmentalist, 19, 145 (1998)

20. M. Boström, Sustainability: Science, Practice, \& Policy, 8, 3 (2012)

21. S. Lopez-Ridaura, O. Masera, M. Astier, Ecological Indicators, 2, 135 (2002)

22. B.R. Ssebunya, C. Schader, L. Baumgart, J. Landert, C.Altenbuchner, E. Schmid, M. Stolze, Ecological Economy, 156, 35 (2019)

23. V.M.J. Varajao, P. Oliveira, Procedia Computer Science, 64, 1172 (2015)

24. A. Bressan, M. Pedrini, Tourism Planning and Development, 17(5), 497 (2020)

25. WTTC, Domestic tourism importance and economic impact, https://wttc.org/ (2018)

26. S. Kvale, Qualitative Inquiry, 12(3), 480 (2006)

27. P. Coleman, International Journal of Caring Sciences, 12(3), 1879 (2019)

28. J. Creswell, International, Educational and Professional Publisher, 342 (2014) 